\title{
7. NEOGENE DIATOMS FROM DEEP SEA DRILLING PROJECT LEG $62^{1}$
}

\author{
Constance A. Sancetta, Lamont-Doherty Geological Observatory \\ of Columbia University, Palisades, New York
}

\section{INTRODUCTION}

All sites cored on Leg 62 lie between $20^{\circ} \mathrm{N}$ and $40^{\circ} \mathrm{N}$ in the central western Pacific, a region of very low diatom productivity. Thus, it is not surprising that diatoms are absent or of minor importance at these sites. Only in the Neogene of Site 464 do they attain any real significance.

This location of the Leg 62 sites in middle latitudes has both advantages and disadvantages for biostratigraphy and paleoceanographic interpretation. On the one hand, because both warm-water (tropical) and coolwater (subarctic) species are present, it is possible to use the zonations of both Burckle (1972, 1978; Burckle and Opdyke 1977) and Koizumi (1975a, 1977), which allows greater resolution than the use of either one alone. However, the middle latitudes are marginal to the regions in which the two zonations were established, so that certain marker species do not occur at all, whereas others have a somewhat different range (usually shorter) than in the source regions. First and last appearances may thus be due to environmental rather than evolutionary events.

Figure 1 compares the two biostratigraphic zonations used, and includes the age ranges currently accepted for some of the important species encountered in Leg 62 sediments.

\section{OCCURRENCE OF DIATOMS AT EACH SITE}

Diatoms are consistently present only in the Neogene of Sites 464 and 466 . For these two sites, Tables 1 and 2 show the preservation and abundance of diatoms in each sample studied.

\section{Site 463}

No diatoms were recovered at Site 463 , in the MidPacific Mountains $\left(21^{\circ} 21^{\prime} \mathrm{N}, 174^{\circ} 40^{\prime} \mathrm{E}\right)$.

\section{Site 464}

Diatoms are present in Lithologic Units IA and IB (clayey radiolarian ooze and siliceous clay), which occur in Cores 1 through 5 (Table 1). Abundance and preservation are best from Core 2 through Core 4, Section 3 $(3.5-27 \mathrm{~m})$. Below this, clay content increases, and the number of diatoms decreases; diatoms are essentially absent below Core 5, Section $3(36.5 \mathrm{~m})$.

Core $1(0-3.5 \mathrm{~m})$ consists of two manganese-encrusted blebs of sediment, in which the diatoms are fairly

\footnotetext{
${ }^{1}$ Initial Reports of the Deep Sea Drilling Project, Volume 62.
}

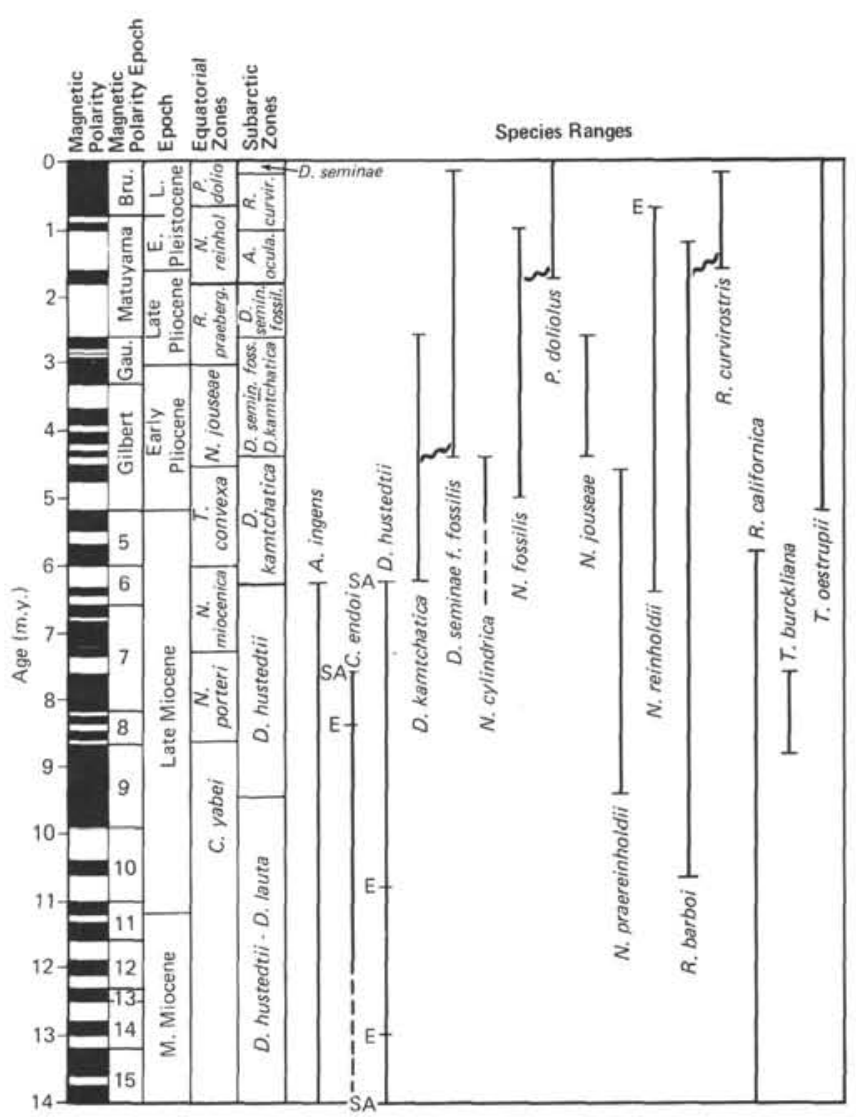

Figure 1. Age ranges of marker species encountered on Leg 62. Ages are those reported by Burckle $(1972,1978$; Burckle and Opdyke, 1977) and Koizumi (1975a, 1977). Wavy lines indicate an evolutionary transition. Broken lines indicate that the age of an event has not been established precisely. Diachronous events are labeled as $\mathrm{E}$ (equatorial) or SA (subarctic).

well preserved, but very fragmented. The presence of Nitzschia fossilis, $N$. reinholdii, Pseudoeunotia doliolus, and Rhizosolenia curvirostris limits this core to the Nitzschia reinholdii Zone, probably equivalent to the Actinocyclus oculatus Zone, in the early Pleistocene.

The interval from Core 2 through Core 3, Section 2 (3.5-16 m) contains Nitzschia fossilis, N. reinholdii, and scattered Denticula kamtchatica and $N$. jouseae; it represents the early Pliocene. These species characterize the lower Rhizosolenia praebergonii and the Nitzschia jouseae Zones, equivalent to the Denticula seminae fossilis-D. kamtchatica and upper D. kamtchatica Zones. Below this interval there is a sequence (Core 3, Section 3 through Core 4, Section 2; 16-24 m) for which 
Table 1. Occurrence of diatoms at Site 464.

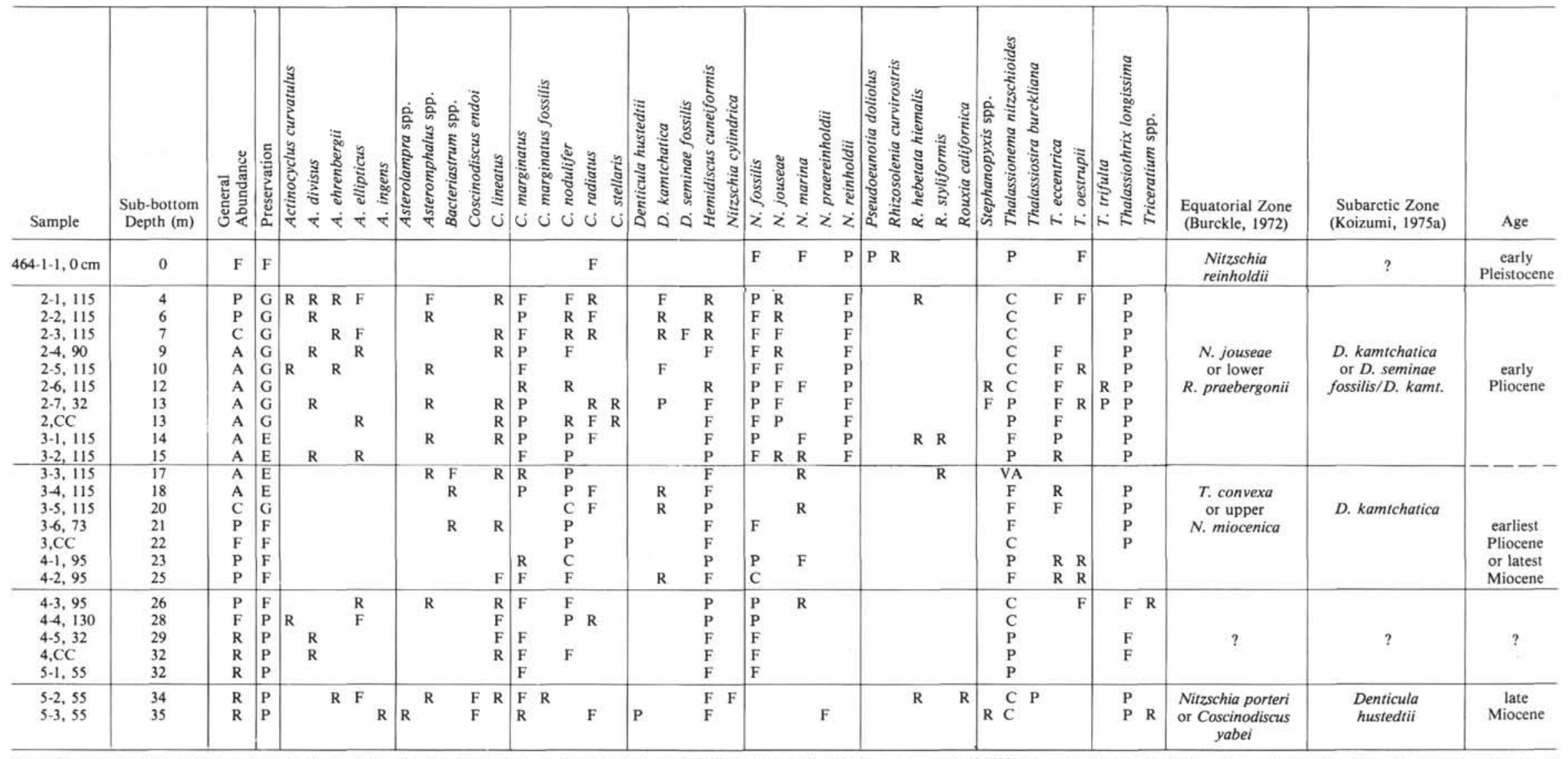

Note: $\mathrm{Abundance}$ terms are $\mathrm{B}=$ barren, $0 \% ; \mathrm{VR}=$ very rare, $0-2 \% ; \mathrm{R}=$ rare, $2-5 \% ; \mathrm{F}=$ few, $5-15 \% ; \mathrm{P}=$ present, $15-40 \% ; \mathrm{C}=$ common, 40-60\%; $\mathrm{A}=$ abundant, $60-85 \% ; \mathrm{VA}=$ very abundant, $85-100 \%$. Preservation terms are $\mathrm{P}=$ poor, highly fragmented, resistant species only; $\mathrm{F}=$ fair, fragments common, mostly resistant species, $\mathrm{G}=$ good, whole valves, some thin-walled forms present; $\mathrm{E}=$ excellent, thin-walled species well preterms are $\mathrm{P}=$ poor, highly fragmented, resistant species only; $\mathrm{F}=$ fair, fragments common, mosty resistant species, $\mathrm{G}=$ good, whole valves, some thin-walled for
served. (Values for species refer to abundance relative to other diatoms, while values for general abundance refer to diatoms relative to other sediment components.) 
Table 2. Occurrence of diatoms at Site 466.

\begin{tabular}{|c|c|c|c|c|c|c|c|c|c|c|c|c|c|c|}
\hline Sample & $\begin{array}{l}\text { Sub-bottom } \\
\text { Depth (m) }\end{array}$ & 总 & 芯 & 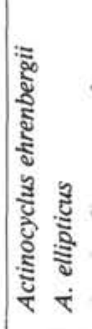 & 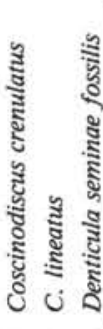 & 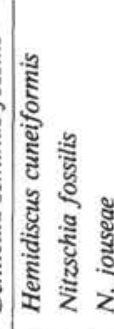 & 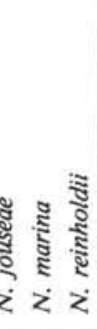 & 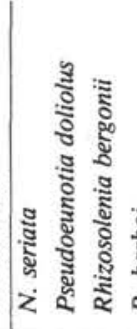 & 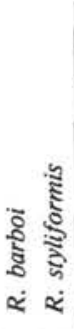 & 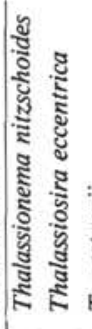 & 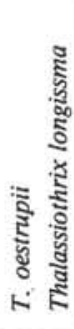 & $\begin{array}{c}\text { Equatorial Zone } \\
\text { (Burckle, 1972) }\end{array}$ & $\begin{array}{c}\text { Subarctic } \\
\text { Zone } \\
\text { (Koizumi, } \\
\text { 1975a) }\end{array}$ & Age \\
\hline $\begin{array}{c}466-1-1,0 \mathrm{~cm} \\
1-1,83 \\
1-2,83 \\
1-3,83 \\
1-4,83 \\
1-6,30 \\
1, \mathrm{CC} \\
2-1,130 \\
\end{array}$ & $\begin{array}{l}0 \\
1 \\
2 \\
4 \\
5 \\
8 \\
8 \\
9 \\
\end{array}$ & $\begin{array}{c}\text { VR } \\
\text { R } \\
\mathrm{F} \\
\mathrm{R} \\
\mathrm{R} \\
\mathrm{R} \\
\mathrm{VR} \\
\mathrm{VR} \\
\end{array}$ & $\begin{array}{l}\mathrm{F} \\
\mathrm{F} \\
\mathrm{G} \\
\mathrm{F} \\
\mathrm{F} \\
\mathrm{P} \\
\mathrm{P} \\
\mathrm{F} \\
\end{array}$ & R & $\begin{array}{lll}R & R & R \\
R & \end{array}$ & R & $\begin{array}{l}+ \\
\mathrm{R} \\
\mathrm{F} \\
\mathrm{F} \\
\mathrm{F} \\
\mathrm{F} \\
+ \\
+\end{array}$ & $\begin{array}{rl}+ & + \\
& \mathrm{R} \\
\mathrm{R} & \mathrm{P} \\
& \\
& \mathrm{F} \\
& \mathrm{R} \\
& + \\
& + \\
& +\end{array}$ & $\begin{array}{r}\mathrm{R} \\
\mathrm{R} \\
\end{array}$ & $\begin{array}{ll}+ & \\
\mathrm{C} & \mathrm{R} \\
\mathrm{C} & \mathrm{R} \\
\mathrm{C} & \\
\mathrm{C} \\
\mathrm{P} \\
+ \\
+ \\
+\end{array}$ & $\begin{array}{ll} & \\
& R \\
R & F \\
F & \\
& R \\
P & \\
& \\
+ & \\
\end{array}$ & $\begin{array}{c}\text { Pseudoeunotia } \\
\text { doliolus }\end{array}$ & ? & $\begin{array}{c}\text { late } \\
\text { Pleistocene }\end{array}$ \\
\hline $\begin{array}{l}2-2,130 \\
2-3,130 \\
2-4,130 \\
\end{array}$ & $\begin{array}{l}11 \\
12 \\
14 \\
\end{array}$ & $\begin{array}{c}\text { VR } \\
\text { VR } \\
\text { R } \\
\end{array}$ & $\begin{array}{l}\mathrm{P} \\
\mathrm{F} \\
\mathrm{F} \\
\end{array}$ & & + & & $\begin{array}{l}++ \\
+ \\
\mathrm{F}^{+}\end{array}$ & $\begin{array}{l}+ \\
+ \\
\mathrm{F}\end{array}$ & + & $\begin{array}{ll}+ & \\
+ & \\
C & R\end{array}$ & $\begin{array}{l}+ \\
P\end{array}$ & $\begin{array}{l}\text { Nitzschia } \\
\text { reinholdii }\end{array}$ & ? & $\begin{array}{c}\text { early } \\
\text { Pleistocene }\end{array}$ \\
\hline $\begin{array}{l}2-5,130 \\
2-6,130\end{array}$ & $\begin{array}{l}15 \\
17\end{array}$ & $\begin{array}{l}\text { B } \\
\text { B }\end{array}$ & & & & & & & & & & ? & ? & ? \\
\hline $\begin{array}{l}2, \mathrm{CC} \\
3-1,112 \\
3-2,112 \\
3-3,112 \\
3-4,112 \\
3-5,112 \\
3, \mathrm{CC} \\
4-1,106 \\
4-2,106 \\
4, \mathrm{CC}\end{array}$ & $\begin{array}{l}17 \\
19 \\
20 \\
22 \\
23 \\
25 \\
27 \\
28 \\
29 \\
36\end{array}$ & $\begin{array}{c}\text { VR } \\
\text { VR } \\
\text { R } \\
\text { R } \\
\text { R } \\
\text { B } \\
\text { B } \\
\text { VR } \\
\text { VR } \\
\text { B }\end{array}$ & $\begin{array}{l}\mathrm{P} \\
\mathrm{P} \\
\mathrm{F} \\
\mathrm{F} \\
\mathrm{P}\end{array}$ & & $\begin{array}{l}R \\
R\end{array}$ & $\begin{array}{ll}\mathrm{R} & \mathrm{R} \\
\mathrm{F} & \mathrm{P} \\
& \mathrm{F} \\
& \\
& \\
& \\
& + \\
+ & +\end{array}$ & $\begin{array}{ll}+ & + \\
+ & + \\
\text { F } & \text { C } \\
\text { R } & \text { P } \\
\text { P } & \text { P } \\
& \\
& \\
+ & + \\
& +\end{array}$ & & $\begin{array}{l}+ \\
\mathrm{F} \\
\mathrm{F}\end{array}$ & $\begin{array}{ll}\mathrm{P} & \mathrm{R} \\
\mathrm{P} & \mathrm{R} \\
\mathrm{C} & \\
& \\
& \\
+ & \\
+ & \end{array}$ & $\begin{array}{ll}\mathrm{F} & \mathrm{R} \\
& \mathrm{F} \\
& \\
& \\
& \\
& +\end{array}$ & ? & ? & Pliocene \\
\hline $\begin{array}{l}5-1,63 \\
5-2,63\end{array}$ & $\begin{array}{l}37 \\
39\end{array}$ & $\begin{array}{l}\text { VR } \\
\text { VR }\end{array}$ & $\begin{array}{l}\mathrm{P} \\
\mathrm{P}\end{array}$ & + & + & $\begin{array}{l}+ \\
+\end{array}$ & $\begin{array}{l}+ \\
+ \\
+\end{array}$ & & & + & & $\begin{array}{c}\text { Nitzschia jouseae } \\
\text { or lower } \\
\text { Rhizosolenia } \\
\text { praebergonii }\end{array}$ & ? & $\begin{array}{c}\text { early } \\
\text { Pliocene }\end{array}$ \\
\hline
\end{tabular}

Note: $+=$ taxon present in sample with very rare diatoms; no attempt to assess relative abundance. Other symbols as in Table 1.

the age is uncertain. $N$. fossilis, $N$. reinholdii, and occasional $D$. kamtchatica are the only stratigraphic markers present. If the absence of $N$. jouseae is evolutionary (i.e., if this interval represents a period prior to the appearance of $N$. jouseae), the principle of superposition would indicate that this section represents the Thalassiosira convexa or upper Nitzschia miocenica Zone (equivalent to the Denticula kamtchatica Zone) of the very early Pliocene or latest Miocene. This interpretation is used in Figure 2, but it must be stressed that unequivocal Miocene marker species are absent. Diatoms become more abundant and better preserved upward through Core 3 , and then become slightly less abundant above Core 2, Section $4(9.5 \mathrm{~m})$, although their general abundance and preservation remain good throughout. In general, the samples are dominated by a constant assemblage of warm-water species; however, there are two interesting variations in this pattern. One is the occurrence of an almost pure Thalassionema nitzschioides ooze in Sample 464-3-3, $115 \mathrm{~cm}(17 \mathrm{~m})$. The other is a slight increase above this level of cooler-water species, such as Coscinodiscus marginatus and Actinocyclus divisus. In particular, Samples 464-2-6, $115 \mathrm{~cm}$ through 464-2,CC (12-13 m) contain rare Stephanopyxis spe- cies, Coscinodiscus stellaris, and Thalssiosira trifulta, which in modern oceans characterize cold, highly productive regions (see Paleoenvironmental Remarks).

Between Samples 464-4-3, $95 \mathrm{~cm}$ and 464-5-2, $55 \mathrm{~cm}$ (26.5-34 m), diatoms are rather rare, and few biostratigraphically important species are present. Stratigraphic position indicates that these samples are also late Miocene or early Pliocene.

In Core 5, diatoms are rare and usually fragmented, but Sections 2 and 3 (33.5-35 m) contain Denticula hustedtii, Actinocyclus ingens, Nitzschia cylindrica, Rouxia californica, Thalassiosira burckliana, Coscinodiscus endoi, and possible Nitzschia praereinholdii. Thus, the samples represent the lower Nitzschia porteri or upper Coscinodiscus yabei Zones of the late Miocene, equivalent to the middle to lower Denticula hustedtii Zone.

\section{Site $\mathbf{4 6 5}$}

At Site 465 , diatoms were recovered only from the top part of Core $465-1$, Section $1(50 \mathrm{~cm})$. They are very rare and poorly preserved. The only species present are Nitzschia marina, Thalassionema nitzschioides, Pseudoeunotia doliolus, Coscinodiscus radiatus, Actinocyclus 
ehrenbergii, and Thalassiosira oestrupii, warm-water species of the Quaternary (Pseudoeunotia doliolus Zone).

\section{Site 466}

Diatoms are rare throughout the first five cores from Site 466 and are absent below Sample 466-5-2, $63 \mathrm{~cm}$ (39 $\mathrm{m}$; Table 2). Several samples within this interval are also barren. The assemblage consists of warm-water elements, with only scattered individuals of cool-water affinity.

The interval from Core 1 through Core 2, Section 1 (0-9.5 m) contains Pseudoeunotia doliolus and rare Denticula seminae fossilis; it is therefore late Pleistocene (Pseudoeunotia doliolus Zone).

Samples 466-2-2, $130 \mathrm{~cm}$ through 466-2-4, $130 \mathrm{~cm}$ (11-14 m) contain rare Pseudoeunotia doliolus and Nitzschia reinholdii, which restrict these samples to the early Pleistocene Nitzschia reinholdii Zone.

Between Samples 466-2-5, $130 \mathrm{~cm}$ and 466-4,CC $(15-36 \mathrm{~m})$, diatoms are either absent or rare, and poorly preserved. The presence of Nitzschia fossilis and $N$. reinholdii, together with the absence of Pseudoeunotia doliolus, suggests that this interval is probably Pliocene, but no zonal assignment can be made.

The upper part of Core 5 (Sections 1 and 2, 36.5-39.5 m) contains Nitzschia jouseae, indicating that at least this portion of Core 5 is early Pliocene, probably within the Nitzschia jouseae Zone (or lower Rhizosolenia praebergonii Zone). Diatoms are undiagnostic or absent below this level.

\section{STRATIGRAPHIC REMARKS}

The series of diatom zones represented at the Leg 62 sites is so incomplete that long-range biostratigraphic correlations cannot be made. However, it may be worthwhile to compare the three DSDP sites on Hess Rise which have yielded diatom floras: 310,464 , and 466. The section at Site 310 (Koizumi, 1975b; Burckle, personal communication) is by far the longest and most complete (Fig. 2), all diatom zones through the Nitzschia porteri Zone being represented. Site 464 definitely has two hiatuses, and may have more, while Site 466 has an undated interval which could include a short hiatus. Thickness of section, and consequently sedimentation rate, varies at different sites, but shows no consistent pattern-certainly the shallowest site is only somewhat more complete than the deepest site. Nor do the thicknesses of the zones change in a consistent way along this transect: the Pseudoeunotia doliolus Zone disappears northward, while the Nitzschia reinholdii Zone alternately expands and contracts.

The pattern of sedimentation on Hess Rise may be due either to changes in biologic productivity or to changes in erosion patterns, or both. The consistent presence of the Nitzschia reinholdii and Nitzschia jouseae/lower Rhizosolenia praebergonii intervals may be a result of very high productivity during the early Pliocene and early Pleistocene, with much lower production at other times. Alternatively, productivity may have been relatively constant through time, but erosion by intermediate waters may have occurred, interrupted
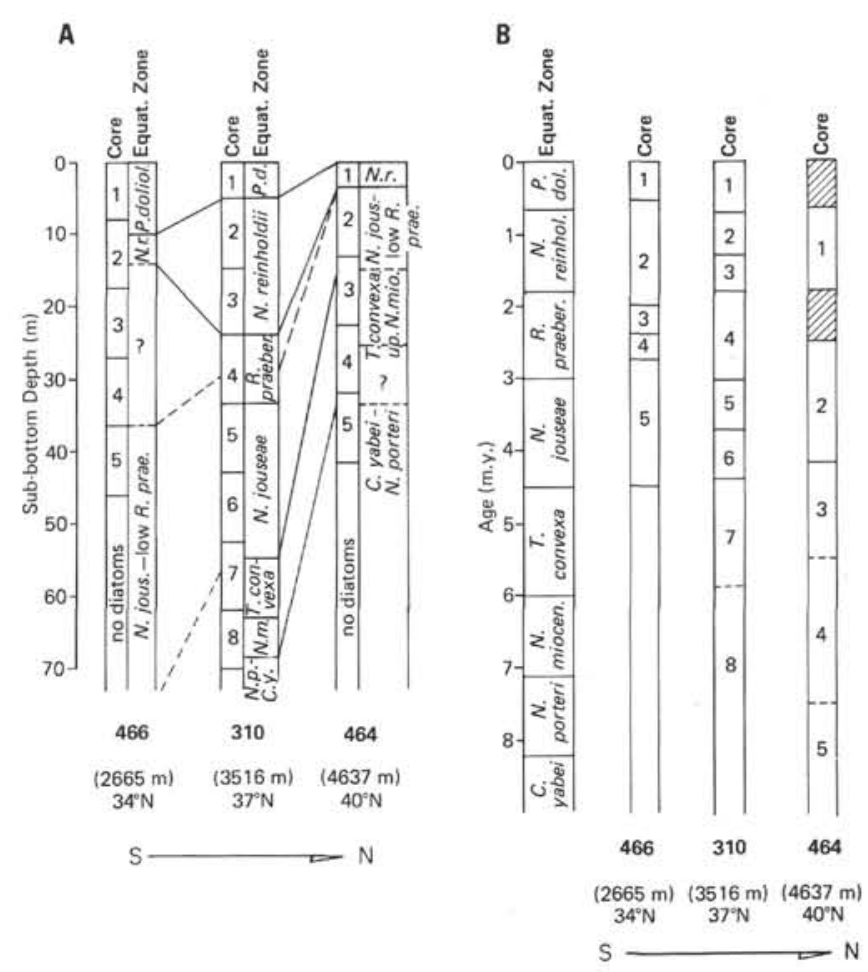

Figure 2. Diatom zones at sites on Hess Rise. Zonation is that of Burckle (1978). Sites represent a north-south transect, water depth increasing northward. A. Zone thicknesses. B. Core ages. Diagonal lines indicate hiatuses at Site 464; question marks represent undated and probably condensed intervals.

during the times corresponding to these two zones, when deposition would have been continuous. This latter explanation, which allows for local variations in current action on the topographically complex Hess Rise, would account for the completeness of the record at Site 310 and the condensed sections and hiatuses at the other sites.

\section{PALEOENVIRONMENTAL REMARKS}

Given the relative paucity of diatoms at Leg 62 sites, it may be somewhat presumptuous to draw any paleoenvironmental conclusions at all. However, two points do seem worthy of note.

First, it may be significant that on the southern part of Hess Rise (Site $466,34^{\circ} 11^{\prime} \mathrm{N}$ ) the diatom flora is almost completely composed of warm-water species, whereas on the northern part of Hess Rise (Site 464, $39^{\circ} 51^{\prime} \mathrm{N}$ ) slightly greater numbers of cool-water species occur. The present subarctic front lies at about $42^{\circ} \mathrm{N}$ (Dodimead et al., 1963) and forms a sharp boundary between assemblages dominated by cool- or warm-water species (Sancetta, 1979). The slight difference between Sites 464 and 466 in the early Pliocene may therefore indicate a front not too far north-certainly no farther north than at present.

The second and more intriguing point is the upward change in floral composition at Site 464, previously mentioned. Within the early Pliocene(?) (Table 1), there 
is a fairly consistent assemblage of warm-water species, followed by a period of almost pure Thalassionema nitzschioides accumulation. Above this level (Sample $464-3-3,115 \mathrm{~cm} ; 17 \mathrm{~m}$ ) the number of cool-water elements increases, although their overall abundance remains low, and some levels contain such taxa as Stephanopyxis species, Coscinodiscus stellaris, and Thalassiosira trifulta. These groups today are characteristic of cold, highly productive waters. $T$. nitzschioides, too, seems to be more abundant in regions of high productivity (Burckle, pers. comm.). It is possible, therefore, that this sequence represents a moderate but distinct cooling of middle-latitude waters, coincident with more vigorous circulation and heightened productivity.

While some workers have found evidence of cooling in the early Pliocene, others have not. Keller (1978) reports two increases in Neogloboquadrina pachyderma (sinistral) at Site 310 , one at $4.7 \mathrm{~m} . \mathrm{y}$. and one at 3.0 m.y. Koizumi (1975b) also indicates an increase in coldwater diatoms at Site 310 , within the Nitzschia jouseae Zone. Keigwin (1978) reports an increase in N. pachyderma (sinistral) in the Panama Basin at about $3.1 \mathrm{~m}$.y. Kennett and Vella (1974) also report several events indicative of early Pliocene cooling in the southwest $\mathrm{Pa}$ cific (ice rafting; increases in sinistral $N$. pachyderma), although the time control of some events is questionable. On the other hand, oxygen isotopes do not show a distinct event within this time. Shackleton and Opdyke (1977), using oxygen isotopes in the central equatorial Pacific, find fairly stable conditions before $3.2 \mathrm{~m}$.y., and an alternating glacial-interglacial regime beginning then. Keigwin (pers. comm.) finds no significant excursions at Site 310, although his sampling interval is rather wide. The age, and even the existence, of this cooling event shown by the diatoms must remain equivocal.

\section{FLORAL REFERENCES}

Because most of the species identified in Tables 1 and 2 are commonly recognized and have been well-reported elsewhere, there is no point in giving detailed descriptions or references. Consequently, I have given only the reference for the original description and, if necessary, a second, more-complete description.

\section{Actinocyclus curvatulus Janisch (1886) [in Schmidt]}

Description. Hustedt (1930).

Remarks. Coscinodiscus curvatulus Grunow (1886) [in Schmidt] has been included, since the distinguishing marginal nodule often is not visible.

Actinocyclus divisus (Grunow) Hustedt (1958)

Description. Hustedt (1930), as Coscinodiscus divisus.

Actinocyclus ehrenbergii Ralfs (1861) [in Pritchard] Description. Hustedt (1930).

Actinocyclus ellipticus Grunow (1880) [in Cleve and Grunow]

Description. Rattray (1890).

Remarks. All varieties are included.

Actinocyclus ingens Rattray (1890)

Asterolampra species

Remarks. Several forms of the genus occur in rare cases. $A$. marylandica and $A$. grevillii were the most common species.

Asteromphalus species

Remarks. Several forms of the genus occur in a few samples. $A$. robustus and $A$. imbricatus were the most common species.

Bacteriastrum species

Remarks. Representatives of this genus are so rarely preserved in the sediment that accurate species distinctions are not possible.

Coscinodiscus crenulatus Grunow (1884)

Description. Hustedt (1930).
Coscinodiscus endoi Kanaya (1959)

Coscinodiscus lineatus Ehrenberg (1838)

Description. Hustedt (1930).

Remarks. All forms have been included; most have a narrow band of very small areolae inside the margin.

Coscinodiscus marginatus Ehrenberg (1841)

Description. Hustedt (1930).

Coscinodiscus marginatus forma fossilis Jousé (1961)

Coscinodiscus nodulifer Schmidt (1886)

Description. Hustedt (1930).

Coscinodiscus radiatus Ehrenberg (1841)

Description. Hustedt (1930).

Cocinodiscus stellaris Roper (1858)

Description. Hustedt (1930).

Denticula hustedtii Simonsen and Kanaya (1961)

Denticula kamtchatica Zabelina (1934)

Denticula seminae forma fossilis Schrader (1973a)

Hemidiscus cuneiformis Wallich (1860)

Description. Hustedt (1930).

Nitzschia cylindrica Burckle (1972)

Nitzschia fossilis (Frenguelli) Kanaya (1970) [in Kanaya and Koizumi]

Nitzschia jouseae Burckle (1972)

Nitzschia marina Grunow (1880) [in Cleve and Grunow]

Nitzschia praereinholdii Schrader (1973b)

Nitzschia reinholdii Kanaya and Koizumi (1970)

Nitzschia seriata Cleve (1883)

Description. Hasle (1972).

Pseudoeunotia doliolus (Wallich) Grunow (1880) [in Cleve and Grunow]

Description. Hustedt (1959),

Rhizosolenia barboi Brun (1894)

Rhizosolenia bergonii Peragallo (1892)

Description. Hustedt (1930).

Rhizosolenia curvirostris Jousé (1968)

Description. Donahue (1970).

Rhizosolenia hebetata forma heimalis Gran (1904)

Description. Hustedt (1930).

Rhizosolenia styliformis Brightwell (1858)

Description. Hustedt (1930).

Rouxia californica Peragallo (1910) [in Tempere and Peragallo]

Stephanopyxis species

Remarks. These rare specimens were not identified to the species level.

Thalassionema nitzschioides Grunow (1880) [in Cleve and Grunow] Description. Hustedt (1959).

Thalassiosira burckliana Schrader (1974)

Thalassiosira eccentrica (Ehrenberg) Cleve (1904)

Description. Hustedt (1930), as Coscinodiscus eccentricus.

Remarks. Most of the observed individuals have a distinct central strutted tubulus.

Thalassiosira oestrupii (Ostenfeld) Proschkina-Lavrenko (1956)

Thalassiosira trifulta Fryxell (1979)

Thalassiothrix longissima Cleve and Grunow (1880)

Description. Hustedt (1959).

Triceratium cinnamomeum Greville (1863)

\section{REFERENCES}

Brightwell, T., 1858. Remarks on the genus Rhizosolenia of Ehrenberg. Quart. J. Miscrosc. Soc., 6:93-95.

Brun, J., 1894. Especes nouvelles. Le Diatomiste, 2(16):72-78; 2(17):86-88.

Burckle, L. H., 1972. Late Cenozoic planktonic diatom zones from the eastern equatorial Pacific. Nova Hedwigia, Beihefte, 39: 217-246.

, 1978. Early Miocene to Pliocene diatom datum levels for the equatorial Pacific. Second Working Group Meeting, Proceedings, IGCP Project 114, Biostratigraphic Datum-Planes of the Pacific Neogene: Bandung, Indonesia (Geol. Res. Dev. Centre), pp. $25-44$.

Burckle, L. H., and Opdyke, N. D., 1977. Late Neogene diatom correlations in the circum-Pacific. Proc. First Internat. Congress Pacific Neogene Stratigraphy, Tokyo, 1976, pp. 255-284.

Cleve, P. T., 1883. Diatoms collected during the expedition of the Vega. Vega-Expedition Iakttagelser, 3:455-517. 
1904. Plankton table for the North Sea. Bull. Conseil Internat. pour l'Exploration de la Mer, 1903-1904:216.

Cleve, P. T., and Grunow, A., 1880. Beitrage zur Kenntniss der arctischen Diatomeen. Konigl. Svenska Vetenskaps-Akademien, Handlingar, 17(2):3-121.

Dodimead, A. J., Favorite, F., and Hirano, T., 1963. Salmon of the North Pacific Ocean II-Review of oceanography of the subarctic Pacific region. Bull. Internat. North Pacific Fisheries Comm., 13:1-95.

Donahue, J. D., 1970. Pleistocene diatoms as climatic indicators in North Pacific sediments. Geol. Soc. Am. Mem., 126:121-138.

Ehrenberg, C. G., 1838. Die Infusionsthierchen als vollkommene Organismen: Liepzig (Leopold Voss), pp. 1-7, pls. 1-548.

, 1841. Uber noch jetzt zahlreich lebende Thierarten der Kreidebildung und den Organismus der Polythalamien. $A b h$. Konigl. Akad. Wiss., Berlin, Physik-Mathem. Klasse, 81-174.

Fryxell, G., 1979. The genus Thalassiosira: $T$. trifulta sp. nova and other species with tricolumnar supports on strutted processes. Nova Hedwigia, Beihefte, 64:13-31

Gran, H. H., 1904. Diatomaceae from the ice-floes and plankton of the Arctic Ocean. In Nansen, F. (Ed.), The Norwegian North Polar Expedition 1893-1896 (Vol. 4):1-74.

Greville, R. K., 1863. Descriptions of new and rare diatoms. Series X. Quart. J. Microsc. Soc., 3 (new ser.):227-237.

Grunow, A., 1884. Die Diatomeen von Franz Josefs-Land, Kaiserl. Akad. Wiss., Wien, Mathem.-Naturw. Klasse, Denkschriften, 48: 55-112.

Hasle, G. R., 1972. The distribution of Nitzschia seriata Cleve and allied species. Nova Hedwigia, Beihefte, 39:171-190.

Hustedt, F., 1930. Die Kieselalgen Deutschlands, Osterreichs und der Schweiz: Liepzig (Akad. Verlag.).

, 1958. Diatomeen aus der Antarktis und dem Sudatlantik. Deutsche Antarktische Exp. 1938-39, 2:104-191.

, 1959. Die Keiselalgen Deutschlands, Osterreichs und der Schweiz: Leipzig (Akad. Verlag.).

Jousé, A. P., 1961. Diatoms and their roles in indicating the history of the oceans. Izv. Akad. Nauk SSSR, Ser. Geograf., 2:13-20. 1968. Species novae Bacillariophytorum in sedimentis fundi Oceani Pacifici et Maris Ochotensis inventae. Akad. Nauk SSSR, Botan. Inst., Novitates Systematicae Plantorum non Vasculorum, 3:12-21.

Kanaya, T., 1959. Miocene diatom assemblages from the Onnagawa Formation and their distribution in the correlative formations in northeast Japan. Tohoku Univ., Sendai, Japan, Scientific Reports (ser. 2), 30:1-130.

Kanaya, T., and Koizumi, I., 1970. The progress in the younger Cenozoic diatom biostratigraphy in the northern circum-Pacific region. J. Mar. Geol., 6(2):47-66.

Keigwin, L. D., 1978. Pliocene closing of the Isthmus of Panama, based on biostratigraphic evidence from nearby Pacific Ocean and Caribbean Sea cores. Geology, 6:630-634.

Keller, G., 1978. Late Neogene biostratigraphy and paleoceanography of DSDP Site 310 central North Pacific and correlation with the southwest Pacific. Mar. Micropaleont., 3:97-119.

Kennett, J. P., and Vella, P., 1974. Late Cenozoic planktonic foraminifera and paleoceanography at DSDP Site 284 in the cool sub- tropical South Pacific. In Kennett, J. P., Houtz, R. E., et al., Init. Repts. DSDP, 29: Washington (U.S. Govt. Printing Office), 769-800.

Koizumi, I., 1975a. Late Cenozoic diatom biostratigraphy in the circum-North Pacific region. J. Geol. Soc. Japan, 81:611-627. 1975b. Neogene diatoms from the northwestern Pacific Ocean, Deep Sea Drilling Project. In Larson, R. L., Moberly, R., et al., Init. Repts. DSDP, 32: Washington (U.S. Govt. Printing Office), 865-889. , 1977. Diatom biostratigraphy in the North Pacific region. Proc. First Internat. Congress Pacific Neogene Stratigraphy, Tokyo, 1976, pp. 235-253.

Peragallo, H., 1892. Monographie du genre Rhizosolenia et de quelques genres voisins. Le Diatomiste, 1(8):72-82; 1(9):99-117.

Pritchard, A. (Ed.), 1861. A History of Infusoria: London (Whittaker).

Proschkina-Lavrenko, A. I., 1956. De specie nova Thalassiosira e Mari Maeotica. Akad. Nauk SSSR, Botan. Inst., Otd. Sporovykh Rastenii, Botan. Mat., 11:57-60.

Rattray, J., 1890. A revision of the genus Actinocyclus, Ehrb. J. Quekett Microsc. Club (ser. 2), 4:139-212.

Roper, F. C. S., 1858. Notes on some new species and varieties of British marine Diatomaceae. Quart. J. Microscopical Sci., 6:1725.

Sancetta, C. A., 1979. Oceanography of the North Pacific during the last 18,000 years: evidence from fossil diatoms. Mar. Micropaleont., 4:103-123.

Schmidt, A., 1886. Atlas der Diatomaceenkunde: Leipzig (O. R. Reisland).

Schrader, H.-J., 1973a. Stratigraphic distribution of marine species of the diatom genus Denticula in Neogene North Pacific sediments. Micropaleont., 19:417-430.

1973b. Cenozoic diatoms from the northeast Pacific, Leg 18. In Kulm, L. D., von Huene, R., et al., Init. Repts. DSDP, 18: Washington (U.S. Govt. Printing Office), 673-797.

1974. Cenozoic marine planktonic diatom stratigraphy of the tropical Indian Ocean. In Fisher, R. L., Bunce, E. T., et al., Init. Repts. DSDP, 24: Washington (U.S. Govt. Printing Office), 887-967.

Shackleton, N. J., and Opdyke, N. D., 1977. Inception of northern hemisphere glaciation: oxygen isotope and paleomagnetic evidence. Nature, 270:216-218.

Simonsen, R., and Kanaya, T., 1961. Notes on the marine species of the diatom genus Denticula Kutz. Internat. Rev. ges. Hydrob., 46:498-513.

Tempere, J., and Peragallo, H., 1910. Diatomées du Monde Entier (Part 1): Grez-sur-Loing (Arcachon).

Wallich, G. C., 1860. On the siliceous organisms found in the digestive cavities of the salpae, and their relation to the flint nodules of the chalk formation. Trans. Microscopical Soc. London (new ser.), 8:36-55.

Zabelina, M. M., 1934. Diatoms from Tertiary deposits of the eastern coast of Kamchatka. Neft. Geol.-Razv. Inst., (ser. A), 48:3-19. 